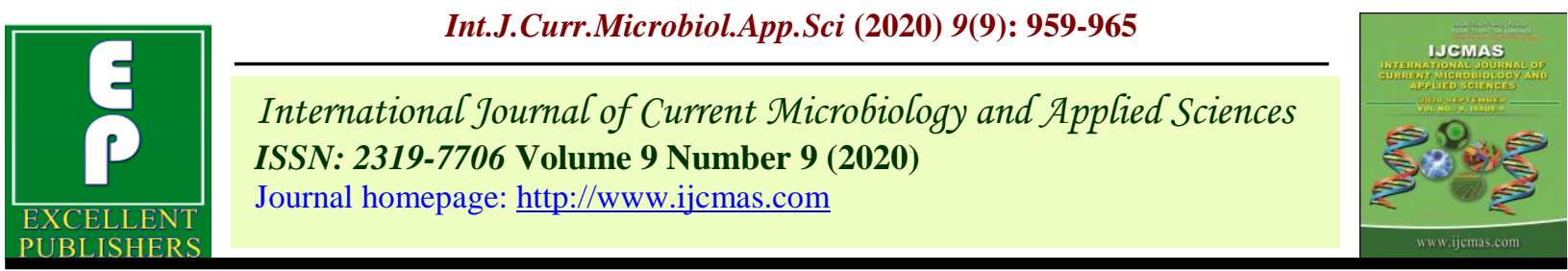

Original Research Article

https://doi.org/10.20546/ijcmas.2020.909.118

\title{
Progress and Performance of Kisan Credit Card Scheme in Different Regions of Rohtak District in Haryana
}

\author{
Madhu Ahlawat and Sumita Singh* \\ Baba Mastnath University, Rohtak, Haryana 124001, India \\ *Corresponding author
}

Keywords

KCC, Production,

Productivity,

Farmer's income,

Total factor

productivity

\section{Article Info}

Accepted:

10 August 2020

Available Online:

10 September 2020

\begin{abstract}
A B S T R A C T
A field study was conducted from the sample KCC holders and actual own experience in the field and discussion with all concerns during the year 2018-19 for the required primary data collection while For collection of the secondary data on the Kisan Credit Card Scheme, were taken for five years i.e. from 2014-15 to 2018-19 as the reference period at different locations of the Rohtak district of Haryana state to find out the utilization pattern of kisan credit card by the farmers, to analyze the constraints faced by the farmers while issuing of KCC and repayment of loan and the strategies to overcome these constraints, to analyze the impact of KCC on the enhancement in agricultural production. The research revealed that KCC holders' income was significantly increased. This was statistically confirmed by applying paired t-test to the collected data. KCC scheme had positive impact on agricultural productivity among farmers. The study also highlighted that the total factor productivity among farmers had increased from 1.38 in the pre-loan period to 1.64 in the post-loan period. The average total factor productivity after availing the loan increased by 0.26, which indicates 18.9 percent increased over the pre-loan period. About 24 percent were found to be dependent on informal sources of credit. Majority of the KCC holders fully reduced the agricultural indebtedness. The results of the study reveal that KCC beneficiary farmers have obtained higher production, productivity and net profit when compared with KCC non beneficiary farmers.
\end{abstract}

\section{Introduction}

Agriculture sector is the mainstream of Indian economy and the most important sector of the Indian Economy When any change in the agriculture sector- "positive or negative"- has multiple effect on the entire economy Therefore; the sustainable development of agriculture is the most important for acceleration in the Indian economy. Agriculture development is influenced by several factors like as irrigation, market, infrastructure and credit (Hooda, 2011). Out of these factors credit is crucial input for sustainable development of agriculture. Government of India has been taken several steps in context of agriculture credit. Kisan Credit Card is one of them. In 1998 Kisan Credit Card Scheme was introduced for smoothly flow of agriculture credit. It has emerged as an innovative and indispensable credit delivery mechanism to meet the credit 
needs of farmers in a timely and hassle free manner. Right from its inception the farmers are enjoying the embedded advantages.

The present study is an attempt to analyze the impact of Kisan Credit Card Scheme on agricultural income and productivity among farmers. The focus of the study is on adequacy and timely availability of credit, it also makes assessment of credit utilization, repayment performance, cost of credit, time lag in getting loans and role of the scheme to reduce the agricultural indebtedness.

Government of India has been taken several steps in context of agriculture credit. Kisan Credit Card is one of them (Rajamohan and Subha, 2014). This scheme has facilitated the availability of credit in time and has simplified the procedure for availing loan from banks to a large extent (Nahatkar et al., 2002). Credit is an important component in agriculture with crop loans constituting a major portion of disbursements.

The Kisan Credit Card Scheme was introduced in India in 1998- 99 by then finance minister Yashwant Sinha. Kallur, M.S. (2005). Consequent to this NABARD has prepared a model kisan credit card scheme in consultation with the major banks on the basis of R V GUPTA Committee. The sustained and rapid growth in agriculture can be achieved mainly through an increase in productivity which is only possible through provision of adequate and timely credit, on the one hand, and accelerated development and dissemination of improved technologies, on the other (Singh and Sihag, 2018). Sharma (2006) revealed that higher percentage 45.00 percent of the respondents belonged to medium annual income category. Sowjanya (2007) reported that majority $(57.14 \%)$ of the respondents belonged to medium income groups, while 71.42 per cent of the respondents belonged to low income category groups. Parmar (2008) reported that a higher percentage of the beneficiaries $(43.33 \%)$ had medium level of annual income. The net profit was Rs. 24120.11 per hectare in case of KCC beneficiaries and Rs 23551.34 per hectare in case of non-KCC beneficiaries.

\section{Materials and Methods}

\section{Research Design}

A research design is the framework or plan for a study used as a guide in collecting and analyzing data. According to the objective and requirement of a study different type of research design can be use to study different problem. Exploratory research design was used in the present study (Table 1-11).

\section{Area of the study}

Rohtak district of Haryana State was the study area.

\section{Unit of study}

KCC holder's household was the unit of the study.

\section{Sampling method}

In order to fulfillment of the above mentioned objectives, the study was conducted in the Rohtak district of Haryana. The district is divided into three tehsils namely Rohtak, Maham, and Sampla. The district was purposively selected as a newly formed and agriculturally less developed district in the state. For selection of sample KCC holders, five branches in each tehsil which has made a higher progress in implementing Kisan Credit Card scheme were selected. For the selection of respondents a list of all the beneficiaries who benefited under KCC scheme were obtained from the selected bank branches. 
After getting list of beneficiaries (KCC holders), from each branch 20 farmers were selected using simple random sampling with due representation to various types of farmers according to their land-holding size.

Thereby 100 KCC holders from each tehsil were selected for the study. So the numbers of KCC holders selected for the study were 300 .

\section{Period of the study}

For collection of the secondary data on the Kisan Credit Card Scheme, five years i.e. from 2014-15 to 2018-19 were taken as the reference period. The required primary data were collected from the sample KCC holders and actual own experience in the field and discussion with all concerns during the year 2018-19.

Table.1 Tehsil - wise list of surveyed branches of the District Rohtak

\begin{tabular}{|l|l|l|l|}
\hline S.No. & Tehsil & S.No. & Bank Branches \\
\hline $\mathbf{1 .}$ & Rohtak & 1. & SBI, Rohtak \\
\hline & & 2. & DCCB, Rohtak \\
\hline & & 3. & Bank of India, Rohtak \\
\hline & & 4. & PNB, Rohtak \\
\hline & & 5. & Union Bank of India, Rohtak \\
\hline 2. & Maham & 1. & SBI, Maham \\
\hline & & 2. & RRB, Maham \\
\hline & & 3. & DCCB, Maham \\
\hline & & 4. & UCO, Maham \\
\hline & & 5. & Union Bank of India, Maham \\
\hline 3. & Sampla & 1. & SBI, Sampla \\
\hline & & 2. & DCCB, Sampla \\
\hline & & 3. & RRB, Sampla \\
\hline & & 4. & PNB, Sampla \\
\hline & & 5. & Union Bank of India, Sampla \\
\hline
\end{tabular}

Table.2 Land type -wise distribution of the sample KCC Holders

\begin{tabular}{|c|c|c|c|c|}
\hline Land Type & \multicolumn{3}{|c|}{ Tehsil } & Total \\
\hline Irrigated & Rohtak & Maham & Sample & \\
\hline Non Irrigated & 85 & 82 & 80 & $247(82.3)$ \\
\hline Total & 15 & 13 & 15 & $53(17.7)$ \\
\hline
\end{tabular}

Source: Field Survey. Figures in parentheses indicate percentage to total

Table.3 Impact of KCCS on agricultural income

\begin{tabular}{|l|l|l|l|l|l|l|}
\hline \multicolumn{1}{|c|}{ Particulars } & \multicolumn{4}{c|}{ Category of Sample KCC Holder } & \multicolumn{1}{c|}{ Total } \\
\hline & \multicolumn{1}{|c|}{ Marginal } & \multicolumn{1}{|c|}{ Small } & \multicolumn{1}{c|}{ Semi Medium } & Medium & \multicolumn{1}{c|}{ Large } & \\
\hline Mean Pre Loan (Rs.) & 21081.08 & 32415.73 & 49584.90 & 111685.19 & 242142.86 & 61140.00 \\
\hline Mean Post Loan (Rs.) & 35135.14 & 56595.50 & 88433.96 & 193425.92 & 413928.57 & 106503.33 \\
\hline Difference In Income (Rs.) & 14054.06 & 24179.77 & 38849.06 & 81740.73 & 171785.71 & 45363.33 \\
\hline \% Change In Income & 66.67 & 74.59 & 78.35 & 73.19 & 70.94 & 74.19 \\
\hline
\end{tabular}


Table.4 Impact of KCC on agricultural productivity

\begin{tabular}{|c|c|c|c|c|}
\hline \multirow{2}{*}{ Particulars } & \multicolumn{3}{|c|}{ Category Of Sample KCC Holder } & \multirow{2}{*}{ Total } \\
\cline { 2 - 5 } & MARGINAL & SMALL & LARGE & \\
\hline TFP Before KCC & 1.25 & 1.39 & 1.34 & 1.38 \\
\hline TFP After KCC & 1.43 & 1.61 & 1.63 & 1.64 \\
\hline Difference In TFP & 0.18 & 0.22 & 0.29 & 0.26 \\
\hline \% Change In TFP & 14.4 & 15.8 & 21.6 & 18.9 \\
\hline
\end{tabular}

Source: Field Survey

Table.5 Source of Irrigation -wise distribution of the sample KCC holders

\begin{tabular}{|c|c|c|c|c|}
\hline Source of Irrigation & \multicolumn{3}{|c|}{ Tehsil } & Total \\
\hline & Rohtak & Maham & Sampla & \\
\hline Tube Well & 29 & 35 & 26 & $80(32.4)$ \\
\hline Pond & 10 & 08 & 06 & $24(9.7)$ \\
\hline Well & 32 & 24 & 31 & $87(35.3)$ \\
\hline River & 19 & 14 & 17 & $50(20.2)$ \\
\hline Canal & 03 & 01 & 02 & $06(2.4)$ \\
\hline Total & 83 & 82 & 82 & $300(100)$ \\
\hline
\end{tabular}

Figures in parentheses indicate percentage to total

Source: Field Survey

Table.6 Land type -wise distribution of the sample KCC holders

\begin{tabular}{|c|c|c|c|c|}
\hline Land Type & \multicolumn{3}{|c|}{ Tehsil } & Total \\
\hline Irrigated & Rohtak & Maham & Sampla & \\
\hline Non Irrigated & 85 & 82 & 80 & $247(82.3)$ \\
\hline Total & 15 & 13 & 15 & $53(17.7)$ \\
\hline
\end{tabular}

Figures in parentheses indicate percentage to total Source: Field Survey

Table.7 Gender -wise distribution of the sample KCC holders

\begin{tabular}{|c|c|c|c|c|}
\hline Gender & \multicolumn{3}{|c|}{ Tehsil } & Total \\
\hline Male & Rohtak & Maham & Sampla & \\
\hline Female & 80 & 90 & 80 & $250(83.33 \%)$ \\
\hline Total & 20 & 15 & 15 & $50(16.67 \%)$ \\
\hline
\end{tabular}


Table.8 Age-wise distribution of the sample KCC holders

\begin{tabular}{|c|c|c|}
\hline Age Group & Number of KCC Holders & Percentage of Total \\
\hline $\mathbf{1 8 - 2 5}$ & 27 & 9.0 \\
\hline $\mathbf{2 5 - 3 2}$ & 29 & 9.7 \\
\hline $\mathbf{3 2 - 3 9}$ & 114 & 38.0 \\
\hline $\mathbf{3 9 - 4 6}$ & 93 & 31.0 \\
\hline $\mathbf{4 6 - 5 3}$ & 14 & 4.7 \\
\hline Above 53 & 23 & 7.7 \\
\hline Total & 300 & 100 \\
\hline
\end{tabular}

Source: Field Survey

Table.9 Family size of the sample KCC holders

\begin{tabular}{|c|c|c|}
\hline Family Size & Number of KCC Holders & Percentage to Total \\
\hline Upto 2 & 72 & 24.0 \\
\hline $3-5$ & 174 & 58.0 \\
\hline $\mathbf{6 - 8}$ & 47 & 15.7 \\
\hline Above 8 & 7 & 2.3 \\
\hline Total & 300 & 100 \\
\hline
\end{tabular}

Source: Field Survey

Table.10 Education-wise distribution of the sample KCC holders

\begin{tabular}{|l|c|c|c|l|}
\hline Education & \multicolumn{3}{|c|}{ Tehsil } & Total \\
\hline Illiterate & Rohtak & Maham & Sampla & \\
\hline Primary & 42 & 45 & 44 & $131(43.66)$ \\
\hline Middle & 22 & 21 & 25 & $68(22.66)$ \\
\hline High School & 21 & 19 & 15 & $55(18.3)$ \\
\hline Higher Secondary & 9 & 9 & 8 & $26(8.66)$ \\
\hline Graduate and above & 4 & 4 & 5 & $13(4.33 \%)$ \\
\hline Total & 2 & 2 & 3 & $07(2.33)$ \\
\hline
\end{tabular}

Figures in parentheses indicate percentage to total Source: Field Survey 
Table.11 Impact on productivity before and after KCC

\begin{tabular}{|c|c|c|}
\hline Parameters & \multicolumn{1}{|c|}{ Before taking KCC } & After taking KCC \\
\hline & Marginal farmers (0-2.5 acres) \\
\hline Productivity (q./ha.) & 40 & 43.50 \\
\hline Gross income (Rs/ha.) & 51450.50 & 68120.40 \\
\hline Net income (Rs/ha.) & 16302 & 24800 \\
\hline & Small farmers (2.5-5 acres) & \\
\hline Productivity (q./ha.) & 40.20 & 43.70 \\
\hline Gross income (Rs/ha.) & 51707 & 68433.59 \\
\hline Net income (Rs/ha.) & 16383.51 & 24914.02 \\
\hline & Large farmers (>5 acres) \\
\hline Productivity (q./ha.) & 40.73 & 44.00 \\
\hline Gross income (Rs/ha.) & 52389.47 & 68903.39 \\
\hline Net income (Rs/ha.) & 16599.51 & 25085.05 \\
\hline
\end{tabular}

\section{Results and Discussion}

In conclusion

The results of the study would be useful to the farmers of ROHTAK in particular and of HARYANA in general, identifying the KCC scheme progress, impact, utility, constraints at the farmer level.

The findings would be helpful to the farmers for making appropriate decisions and how best the available credit resources could be judiciously utilized for increased farm income.

This study would be useful for financial institutes to assess the financial needs of the farmers and their constraints in availing loans.

At the micro level this study also guides the farmers to depend upon financial sources of loans rather than noninstitutional sources and helpful to the planners, administrators and research workers for better planning and implementation.

From this research the observed data could be utilized to know the various constraints responsible for the success of the KCC

The observed data will help in understanding, what are the various changes that is needed at credit institutional level for the easy availment as well as repayment of the loan.

Ultimately this research will be helpful in the betterment of the farmers as a unit and country as a whole.

\section{References}

Hooda, V.S. (2011). Kisan Credit Card Scheme: A Success Story. Kurukshetra. 59(8): 19 - 22.

Kallur, M.S. (2005), "Impact of Kisan Credit Card on Flow of Credit and Repayment Rate in a Backward Region: A case of Agricultural Development Bank of Shorapur Taluka, Gulbarga District, Karnataka State," Indian Journal of Agricultural Economics. 60(3):396

Nahatkar, S.B., Mishra, P.K., Raghuwanshi, N.K. and Beohar, B.B. (2002) An evaluation of Kisan Credit Card scheme: A case study of Patan tehsil of Jabalpur district of Madhya Pradesh, Indian Journal of Agricultural Economics, 57(3): 578.

Parmar, S.K. (2008). A study on repayment 
behaviour of beneficiaries of Kisan Credit Card scheme in Sehore block of Sehore district of Madhya Pradesh. M.Sc. (Ag) Thesis submitted to J.N.K.V.V. Jabalpur.

Rajamohan S and Mrs.K.Subha K. (2014). Kisan Credit Card Scheme in India: a Facet of Financial Inclusion International Journal of Scientific Research. 3(10): 2277 - 8179

Sharma, S.K. (2006). A study on functioning of Kisan Seva Kendras (KSKs) in Udaipur district of Rajasthan. M.Sc. (Agri.) Thesis, University of
Agricultural Sciences, Dharwad.

Singh, A and Sihag, S. (2018). Impact of kisan credit card scheme on farm economy of farmers in karnal district with special reference to wheat crop. International educational and research journal, 4(5): 2454-9916.

Sowjanya (2007). A comparative analysis of successful and unsuccessful selfhelp groups in Gadag District of Karnataka. M.Sc. (Agri.) Thesis, University of Agricultural Sciences, Dharwad.

\section{How to cite this article:}

Madhu Ahlawat and Sumita Singh. 2020. Progress and Performance of Kisan Credit Card Scheme in Different Regions of Rohtak District in Haryana. Int.J.Curr.Microbiol.App.Sci. 9(09): 959-965. doi: https://doi.org/10.20546/ijcmas.2020.909.118 